\title{
PENGARUH KUALITAS PELAYANAN DI ERA BPJS TERHADAP KEPUASAN 1 PASIEN RAWAT JALAN PADA POLIKLINIK MATA (STUDI KASUS PADA RUMAH SAKIT BHAYANGKARA SEMARANG)
}

\author{
Lala Irviana \\ Departemen Manajemen, Universitas Diponegoro, Semarang, Indonesia \\ lalairviana@lecturer.undip.ac.id
}

\begin{abstract}
ABSTRAK
Penelitian ini bertujuan untuk mengklarifikasi dan mengetahui pengaruh kualitas layanan terhadap kepuasan pelanggan secara bersama-sama dan parsial serta untuk mengetahui variabel mana yang dominan mempengaruhi kepuasan pelanggan di Rumah Sakit Bhayangkara Semarang (Opthamologist Policlinic). Variabel independen yang digunakan dalam penelitian ini adalah reliabilitas, daya tanggap, kepercayaan diri, empati, dan tangible. Variabel dependen dalam penelitian ini adalah kepuasan pelanggan. Penelitian ini dilakukan di Rumah Sakit Bhayangkara Semarang (Opthamologist Policlinic). Sampel populasi yang digunakan adalah pasien di Rumah Sakit Bhayangkara Semarang. Teknik pengambilan sampel menggunakan Accidental Sampling. Sampel yang digunakan dalam penelitian ini berjumlah 80 pasien sebagai responden. Berdasarkan hasil uji $\mathrm{F}$ menunjukkan bahwa $\mathrm{F}$ hitung lebih besar dari $\mathrm{F}$ tabel, yang berarti kualitas layanan yang terdiri dari keandalan, daya tanggap, kepercayaan, empati, dan berwujud memiliki pengaruh yang signifikan terhadap kepuasan pelanggan. Hasil uji $\mathrm{T}$ juga menunjukkan bahwa variabel empati memiliki efek paling kuat dibandingkan dengan variabel lain seperti keandalan, daya tanggap, kepercayaan dan berwujud, sehingga variabel empati memiliki pengaruh dominan terhadap kepuasan pelanggan (pasien).
\end{abstract}

Kata kunci : Kualitas layanan, keandalan, daya tanggap, kepercayaan, empati, berwujud dan kepuasan pelanggan.

$$
\begin{gathered}
\text { THE INFLUENCE OF SERVICE QUALITY IN BPJS ERA ON THE } \\
\text { SATISFACTION OF PATIENTS IN EYES POLYCLINICS } \\
\text { (CASE STUDY AT THE BHAYANGKARA HOSPITAL, SEMARANG) }
\end{gathered}
$$

\section{ABSTRACT}

This study aims to clarify and determine the effect of service quality on customer satisfaction together and partially and to find out which variables are dominantly affecting customer satisfaction at Bhayangkara Hospital Semarang (Opthamologist Policlinic). The independent variables used in this study are reliability, responsiveness, self-confidence, empathy, and tangibility. The dependent variable in this study is customer satisfaction. This research was conducted at Bhayangkara Hospital Semarang (Opthamologist Policlinic). The 
population sample used was patients at Bhayangkara Hospital Semarang. The sampling technique uses accidental sampling. The sample used in this study amounted to 80 patients as respondents. Based on the results of the F test shows that the $F$ count is greater than the F table, which means that service quality consisting of reliability, responsiveness, trust, empathy, and tangibility has a significant effect on customer satisfaction. $T$ test results also indicate that the empathy variable has the strongest effect compared to other variables such as reliability, responsiveness, trustworthiness and tangibility, so that the empathy variable has a dominant influence on customer (patient) satisfaction.

Keywords: Service quality, reliability, responsiveness, trust, empathy, tangible and customer satisfaction.

Diterima: 15 Maret 2020; Direvisi: 30 Maret 2020; Diterbitkan: 30 April 2020

\section{PENDAHULUAN}

\begin{abstract}
Keberhasilan pembangunan kesehatan disuatu negara sangat menentukan upaya peningkatan kualitas sumber daya penduduknya. Penduduk yang sehat bukan saja akan membantu menunjang keberhasilan program pendidikan, tetapi juga mendorong peningkatan produktivitas dan pendapatan penduduk.
\end{abstract}

Salah satu isu strategis dalam kebijakan pembangunan kesehatan adalah mutu dan keterjangkauan layanan kesehatan. Dipandang dari segi fisik persebaran sarana pelayanan kesehatan baik Puskesmas atau Rumah Sakit serta sarana kesehatan lainnya termasuk sarana penunjang upaya kesehatan telah dapat dikatakan cukup merata ke seluruh pelosok wilayah Indonesia. Namun harus diakui bahwa persebaran fisik tersebut masih belum diikuti sepenuhnya dengan peningkatan mutu pelayanan dan keterjangkauan oleh seluruh lapisan masyarakat. Mutu pelayanan kesehatan sangat dipengaruhi oleh kualitas sarana fisik, jenis tenaga yang tersedia, obat, alat kesehatan dan sarana penunjang lainnya, proses pemberian pelayanan dan kompensasi yang diterima serta harapan masyarakat pengguna (konsumen / pasien). Dengan demikian maka peningkatan kualitas fisik serta faktor-faktor non fisik merupakan pra kondisi yang harus dipenuhi.
Program Indonesia sehat yang disampaikan pada Rapat Kerja Kesehatan Nasional Bidang Kesehatan bulan Februari 2019 mengenai Nawacita No 5 (Undang - Undang Republik Indonesia , Nomor 24 Tahun 2011),(Kesehatan \& Indonesia, 2011) yaitu Peningkatan Kualitas Hidup Manusia Indonesia mengemukakan dalam Program Indonesia sehat ada 3 hal pokok yang perlu menjadi perhatian, yaitu : Paradigma Sehat, Penguatan Yankes, dan JKN (Rencana Strategis Kementerian Kesehatan Tahun 2015-2019).

JKN (Jaminan Kesehatan Nasional) adalah program pelayanan kesehatan dari pemerintah dalam wujud BPJS Kesehatan dan BPJS Ketenagakerjaan dan sistemnya adalah menggunakan sistem asuransi. Dengan adanya JKN ini maka seluruh warga Indonesia berkesempatan besar untuk mendapatkan jaminan kesehatan dengan lebih baik. Dengan hanya menyisihkan sebagian kecil dari pendapatan, maka masyarakat Indonesia akan mampu menjadi peserta dan memperoleh manfaatnya. Untuk masyarakat yang tidak mampu (miskin), iurannya ditanggung oleh Pemerintah atau biasa disebut PBI (Penerima Bantuan Iuran). Berdasarkan uraian diatas, maka tidak ada alasan lagi bagi masyarakat tidak mampu untuk tidak memeriksakan penyakitnya ke fasilitas kesehatan.

BPJS (Badan Penyelenggara Jaminan Sosial) sendiri adalah badan atau perusahaan asuransi yang sebelumnya kita kenal bernama PT Askes, yang menyelenggarakan 
perlindungan kesehatan bagi para pesertanya. Perlindungan kesehatan ini juga bisa didapat dari BPJS Ketenagakerjaan yang merupakan transformasi dari Jamsostek (Jaminan Sosial Tenaga Kerja). Dari masing-masing definisi ini maka bisa disimpulkan bahwa perbedaan diantara keduanya ini adalah bahwa JKN merupakan nama programnya, sedangkan BPJS merupakan badan penyelenggaranya dimana kinerjanya akan diawasi oleh DJSN (Dewan Jaminan Sosial Nasional).

Badan Penyelenggara Jaminan Sosial (BPJS) Kesehatan adalah sebuah sistem Kesehatan yang diharapkan dapat mewujudkan Jaminan Kesehatan (JKN-KIS) yang berkualitas dan berkesinambungan bagi seluruh Penduduk Indonesia berlandaskan gotong royong yang berkeadilan. BPJS Kesehatan sendiri merupakan produk Undang Undang JKN (Jaminan Kesehatan Nasional) yang mewajibkan Pemerintah membiayai ongkos kesehatan di Republik ini dengan strategi yang diatur secara lebih detail oleh Pemerintah, sebagai contoh adalah bagaimana pengaturan sistem BPJS Kesehatan untuk keluarga miskin.

BPJS Kesehatan yang merupakan produk UU No 40/2004 dan UU No 24/2011 sangat berbeda jika dibandingkan dengan sistem sosial sebelumnya seperti : Askes, Jamsostek, Jamkesmas (Undang - Undang Republik Indonesia , Nomor 24 Tahun 2011) Kesehatan dan Indonesia, 2011. Perbedaan yang utama adalah selain BPJS Kesehatan merupakan amanat Undang Undang, perbedaan lainnya adalah mengenai prinsip klaim. Produk terdahulu menggunakan klaim berdasarkan fee for service, sedangkan klaim BPJS Kesehatan berdasarkan sistem paket yang di plafond kan tanpa melihat berapa biaya service nya (INA CBGS).

Kepuasan pasien dalam pelayanan kesehatan adalah hal yang sangat penting untuk dicermati, hal ini dikarenakan kepuaan pasien dapat menggambarkan kualitas pelayanan ditempat pelayanan Kesehatan tersebut. Mengetahui kepuasan pasien sangat bermanfaat bagi instansi terkait dalam rangka evaluasi program yang sedang atau akan dijalankan, serta dapat menemukan bagian mana yang memerlukan peningkatan.

Salah satu ciri sistem kualitas modern, bahwa pelayanan yang berkualitas harus berorientasi kepada pelanggan (internal dan eksternal) yaitu jasa Rumah Sakit yang dihasilkan harus didesain sesuai keinginan pelanggan melalui riset yang berkesinambungan (Guterman, 2015). Pelanggan secara individual menuntut agar diperlakukan secara khusus sesuai kebutuhan individual mereka. Dalam menunjang terjadinya perubahan konsep itu maka didalam organisasi Rumah Sakit perlu ditanamkan bahwa pelanggan (pasien) adalah satu-satunya alasan eksistensi Rumah Sakit. Keberadaan Rumah Sakit ditentukan bukan saja oleh kualitas produk jasa yang diberikan Rumah Sakit, tetapi oleh kemampuan produk / jasa dalam memenuhi kebutuhan pelanggannya secara individual.

Pelanggan atau pasien sudah lebih terdidik, lebih sejahtera dan lebih "informed" tentang kesehatan dan penyakit. Mereka sudah mengetahui tentang hak-haknya, baik hak-hak asasi sebagai manusia maupun hak-hak khusus sebagai pasien. Karena itu tuntutan dan harapannya tentang layanan kesehatan sudah jauh meningkat.

Mereka tidak lagi dengan layanan yang tidak menghormati hak-haknya sebagai manusia dan sebagai pasien. Tantangan bagi Rumah sakit adalah bagaimana mengubah paradigmanya menjadi upaya sungguh-sungguh meningkatkan kepuasan pasien.

Dilihat dari kondisi yang berbeda antara Rumah Sakit yang satu dengan yang lannya, maka perlu adanyakontrol yang harus dilakukan oleh Rumah Sakit baik dalam strategi pemasaran maupun dalam mencermati pengambilan keputusan konsumen untuk mau menjadi pasien yang mau menggunakan jasa yang ditawarkan. Selain itu perlu diketahui variable mana yang mempunyai pengaruh 
penting terhadap kepuasan pasien (Prakash, 2019).

Dari uraian diatas menunjukkan bahwa penelitian kepuasan konsumen merupakan kegiatan yang perlu diperhatikan oleh Rumah Sakit (Yousapronpaiboon, 2014), karena sebuah Rumah Sakit sangat tergantung pada diterima atau tidaknya produk atau jasa yang ditawarkan kepada pasien (Chatzoglou et al., 2014).

Peningkatan jumlah pengunjung tergantung dari kualitas pelayanan yang diberikan oleh sebuah rumah sakit tersebut. Adapun cara untuk mengetahui kualitas pelayanan tersebut harus diketahui dengan mengevaluasi tingkat kepuasan di sarana tersebut. Rumah Sakit Bhayangkara Semarang merupakan salah satu rumah sakit besar di Semarang. Jumlah pasien yang berobat di rumah sakit tersebut relatif banyak. Hal tersebut dapat ditunjukkan dengan laporan catatan tahunan dari unit Rekam medis tentang indeks pasien rawat jalan Rumah Sakit Bhayangkara Semarang selama tahun 2017 2019 dari data yang tercatat jumlah penderita masih mengalami kenaikan dan penurunan.

Disini tidak adanya target dari jumlah pasien rawat jalan yang masuk dikarenakan rumah sakit merupakan perusahaan publik yang mempunyai tujuan sosial dan memberikan pelayanan kesehatan kepada masyarakat pada umumnya. Orang sakit yang menjalani rawat jalan bukan merupakan target rumah sakit, karena diharapkan semua masyarakat sehat sehingga mampu berkarya dengan baik. Tidak seperti dunia perhotelan yang mengedepankan target okupansi kamar hotel dalam strategi pemasarannya (Zumrah, 2014).

Tabel 1. Perkembangan Pasien Rawat Jalan

\begin{tabular}{|c|c|c|c|}
\hline Jenis Pasien & 2017 & 2018 & 2019 \\
\hline Anggota POLRI & 205 & 190 & 313 \\
\hline PNS POLRI & 97 & 54 & 79 \\
\hline Keluarga POLRI & 321 & 364 & 305 \\
\hline BPJS Umum & 2101 & 4786 & 7192 \\
\hline Jumlah & 2724 & 5394 & 7889 \\
\hline
\end{tabular}

Sumber: Unit Rekam Medis tentang Data Penderita Dirawat di Polikilink Mata RS Bhayangkara Semarang
Dari data diatas dapat diketahui bahwa jumlah pasien di Rumah Sakit Bhayangkara Semarang mengalami fluktuasi. Hal ini dapat di ketahui ditahun 2018 mengalami penurunan dari 205 pasien menjadi 190 pasien dibanding tahun 2017 (pasien anggota kepolisian). Sementara pada tahun yang sama mengalami penurunan dari 97 pasien menjadi 54 pasien (pasien PNS).

Guna mempertahankan eksistensi kualitas pelayanan, Rumah Sakit Bhayangkara Semarang harus mampu memberikan jasa pelayanan (A. A. Parasuraman et al., 1991) mengingat banyaknya pesaing yang ada di sekitar Rumah Sakit Bhayangkara Semarang.

\section{KAJIAN TEORETIK}

\section{Kualitas Pelayanan}

(Berry et al., 1988) mengembangkan sebuah model analisa untuk mengukur pengaruh kualitas pelayanan (Service Quality) berdasarkan pandangan pada hubungan secara terpadu antara konsumen dengan Perusahaan. Model ini memberikan lima dimensi dari kualitas pelayanan, yaitu : keandalan (reliability), ketanggapan (responsive), keyakinan (confidence), empati (emphaty), dan bukti fisik (tangible). Sebagai contoh jika konsumen melihat implementasi dari dimensi kualitas pelayanan dalam menyelesaikan kebutuhan sehari-hari sehingga dapat memenuhi kebutuhan dan pengharapan konsumen, maka situasi ini akan mendorong konsumen kearah yang lebih positif. Semangat dari teori ini membawa dukungan yang kuat terhadap literatur penelitian kualitas pelayanan (Zeithaml et al., 1996)

Kualitas adalah sebuah perbandingan antara harapan dengan kinerja (Parasuraman et al., 1985; Mohanty , 2012) . Kualitas layanan digunakan untuk mengukur sebaik apa tingkat pelayanan yang disampaikan kepada konsumen dibandingkan dengan harapan konsumen (Guterman, 2015). 
Keterlibatan adalah sebuah istilah yang pertama kali dipopulerkan oleh (Krugman, 1965), seperti yang bisa dilihat dalam tabel klasifikasi matriks kualitas pelayanan, keterlibatan rendah (tipe A dan tipe B) , konsumen akan melakukan evaluasi berdasarkan kualitas pelayanan yang diterima dengan apa yang diharapkan, sedangkan pada keterlibatan tinggi (tipe $\mathrm{C}$ dan tipe $\mathrm{D}$ ) konsumen akan melakukan evaluasi kualitas pelayanan yang diterima dengan kinerja dari pelayanan itu sendiri. Dalam hal ini pelayanan kesehatan ada pada matiks D (tingkat keterlibatan konsumen tingi dan tingkat kompleksitas tinggi).

Tabel 2.

Tabel Matriks Klasifikasi Kualitas Pelayanan

\begin{tabular}{|c|c|c|c|}
\hline & \multicolumn{2}{|c|}{ Tingkat Kompleksitas } \\
\hline & & Rendah & Tinggi \\
\hline \multirow{7}{*}{$\begin{array}{c}\text { Tingkat } \\
\text { keterlibatan } \\
\text { konsumen }\end{array}$} & Rendah & Tipe $\mathbf{A}$ & Tipe B \\
\hline & & Mesin Teller & Servis IT \\
\hline & & Transportas & Asuransi \\
\hline & & Massa & Jiwa \\
\hline & Tinggi & Tipe C & Tipe D \\
\hline & & Call Center & Konsultasi \\
\hline & & $\begin{array}{l}\text { Restorant } \\
\text { cepat saji }\end{array}$ & $\begin{array}{c}\text { Pemeriksaan } \\
\text { kesehatan }\end{array}$ \\
\hline
\end{tabular}

\section{Kepuasan Konsumen}

Kepuasan konsumen adalah perasaan positif dari seorang konsumen yang muncul dari perbandingan akan pengalaman mengkonsumsi penawaran khusus yang diobservasi dengan kinerja yang diharapkan (Tsiros et al., 2004). Konsumen akan menjadi puas ketika level yang diharapkan sesuai dengan kenyataaan yang diperoleh. Ketika yang diperoleh melebihi harapannya, konsumen akan menjadi sangat puas atau gembira (Kopalle \& Lehmann, 2006).

Kepuasan konsumen secara signifikan dan kritis menggambarkan evaluasi subjektif dari konsumen (Cronin \& Taylor, 1992). Konsumen yang merasa puas dapat dipertimbangkan untuk menggunakan word of mouth yang positif untuk mempengaruhi orang lain mengkonsumsi apa yang telah dikonsumsi olehnya (Mattila \& S, 2001). Selain itu, kualitas pelayanan juga dapat menjadi tolak ukur kepuasan konsumen dan loyalitas konsumen (Ismail \& Yunan, 2015).

\section{Kerangka Penelitian}

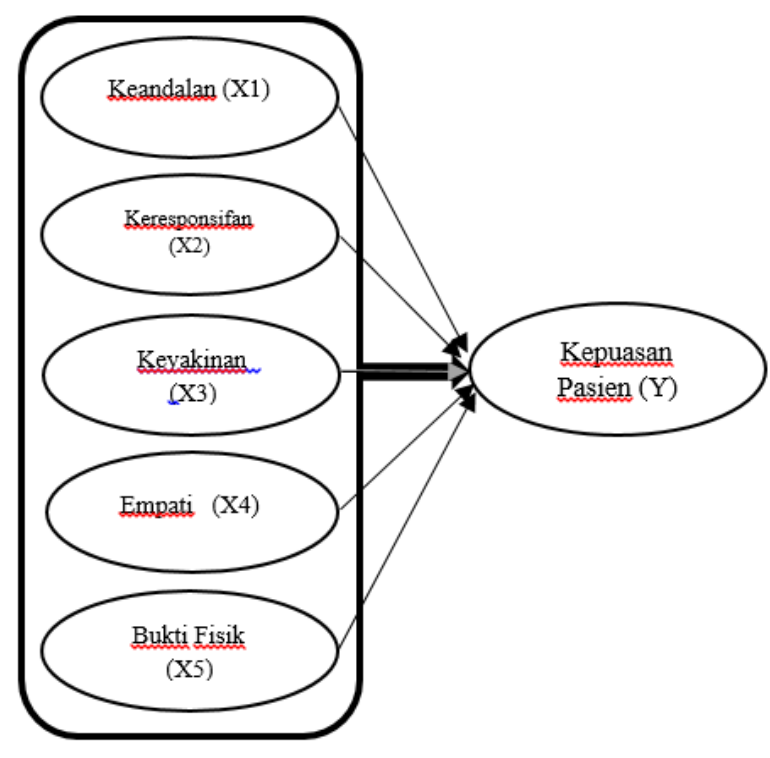

\section{Hipotesis}

$\mathrm{H}_{1}$ : Variabel keandalan berpengaruh terhadap kepuasan pasien

$\mathrm{H}_{2}$ : Variabel keresponsifan berpengaruh terhadap kepuasan pasien

$\mathrm{H}_{3}$ : Variabel keyakinan berpengaruh terhadap kepuasan pasien

$\mathrm{H}_{4}$ : Variabel empati berpengaruh terhadap kepuasan pasien

$\mathrm{H}_{5}$ : Variabel bukti fisik berpengaruh terhadap kepuasan pasien

$\mathrm{H}_{6}$ : Variabel keandalan, keresponsifan, keyakinan, empati, berwujud berpengaruh secara bersama terhadap kepuasan pasien

\section{METODE PENELITIAN}

Penelitian ini merupakan penelitian penjelasan (explanatory research) dengan pendekatan kuantitatif. Penelitian dilakukan pada layanan rawat jalan (poliklinik) penyakit mata di Di Rumah Sakit Bhayangkara Semarang). Ada 80 orang responden yang 
terlibat dalam penelitian ini. Tehnik pengumpulan data menggunakan kuesioner dengan pertanyaan tertutup dan dianalisis, menggunakan regresi linier berganda.

\section{HASIL PENELITIAN}

\begin{tabular}{|c|c|c|c|c|c|c|}
\hline \multicolumn{2}{|c|}{ Variabel } & \multirow{2}{*}{$\begin{array}{c}\text { Koefisien } \\
\text { Regresi }\end{array}$} & \multirow{2}{*}{$\begin{array}{c}\mathrm{T} \\
\text { Hitung }\end{array}$} & \multirow[t]{2}{*}{ Beta } & \multirow[t]{2}{*}{ Sig } & \multirow{2}{*}{$\begin{array}{l}\text { Keterangan } \\
\text { terhadap } \\
\text { Ho }\end{array}$} \\
\hline Terikat & Bebas & & & & & \\
\hline Kons & & $-4,645$ & $-1,934$ & & 0,057 & \\
\hline \multirow{5}{*}{ Y } & $\overline{\mathrm{X} 1}$ & 0,118 & 2,203 & 0,168 & 0,031 & Ditolak \\
\hline & $\mathrm{X} 2$ & 0,247 & 2,906 & 1,226 & 0,005 & Ditolak \\
\hline & $\mathrm{X}_{3}$ & 0,121 & 2,413 & 0,179 & 0,018 & Ditolak \\
\hline & $\mathrm{X}_{4}$ & 0,315 & 4,908 & 0,376 & 0,000 & Ditolak \\
\hline & $\mathrm{X}_{5}$ & 0,276 & 2,846 & 0,221 & 0,006 & Ditolak \\
\hline \multicolumn{2}{|c|}{$\mathrm{R}$} & 0.875 & & & & \\
\hline \multicolumn{2}{|c|}{ R Square } & 0,734 & & & & \\
\hline \multicolumn{2}{|c|}{$\begin{array}{c}\text { Adjusted } R \\
\text { Square }\end{array}$} & 0,716 & & & & \\
\hline \multicolumn{2}{|c|}{ F Hitung } & 40,831 & & & & \\
\hline \multicolumn{2}{|c|}{ Signifikansi } & o & & & & \\
\hline \multicolumn{2}{|c|}{$\mathrm{N}$} & 80 & & & & \\
\hline
\end{tabular}

Sumber : Data Primer diolah, 2019

\section{PEMBAHASAN}

Berdasarkan uji validitas, reliabilitas dan normalitas dengan menggunakan software SPSS, dinyatakan valid, reliabel; dan normal.

\section{Variabel Keandalan $\left(X_{1}\right)$}

Berdasarkan uji $\mathrm{t}$ diperoleh $\mathrm{t}$ hitung $(2,203) \geq t$ tabel $(1,99)$ dengan signifikansi o,o31 menunjukkan bahwa Keandalan $\left(\mathrm{X}_{1}\right)$ mempunyai pengaruh yang signifikan terhadap kepuasan pasien (Y). Sehingga hipotesis pertama $\left(\mathrm{H}_{1}\right)$ dalam penelitian ini diterima. Penelitian ini mendukung penelitian sebelumnya tentang variabel keandalan $\left(\mathrm{X}_{1}\right)$ meliputi kecepatan, ketepatan (Berry et al., 1988) terhadap prosedur penerimaan pasien.

\section{Variabel Keresponsifan $\left(\mathbf{X}_{2}\right)$}

Berdasarkan uji $\mathrm{t}$ diperoleh $\mathrm{t}$ hitung $(2,906) \geq \mathrm{t}$ tabel $(1,99)$ dengan signifikansi 0,005 menunjukkan bahwa Keresponsifan $\left(\mathrm{X}_{2}\right)$ mempunyai pengaruh yang signifikan terhadap kepuasan pasien (Y). Sehingga hipotesis kedua $\left(\mathrm{H}_{2}\right)$ dalam penelitian ini diterima. Variabel keresponsifan $\left(\mathrm{X}_{2}\right)$ meliputi penanganan dan penyelesaian keluhan pasien dengan baik.

\section{Variabel Keyakinan $\left(X_{3}\right)$}

Berdasarkan uji t diperoleh thitung $(2,413)$ $\geq \mathrm{t}$ tabel $(1,99)$ dengan signifikansi 0,018 menunjukkan bahwa Keyakinan $\left(\mathrm{X}_{3}\right)$ mempunyai pengaruh yang signifikan terhadap kepuasan pasien (Y). Sehingga hipotesis ketiga $\left(\mathrm{H}_{3}\right)$ dalam penelitian ini diterima. Variabel keyakinan $\left(\mathrm{X}_{3}\right)$ meliputi ketrampilan dan ketepatan dalam mendiagnosis penyakit yang diderita oleh pasien.

\section{Variabel Empati $\left(\mathbf{X}_{\mathbf{4}}\right)$}

Berdasarkan uji $\mathrm{t}$ diperoleh $\mathrm{t}$ hitung $(4,908) \geq \mathrm{t}$ tabel $(1,99)$ dengan signifikansi o,ooo menunjukkan bahwa Empati $\left(\mathrm{X}_{4}\right)$ mempunyai pengaruh yang signifikan terhadap kepuasan pasien (Y). Sehingga hipotesis keempat $\left(\mathrm{H}_{4}\right)$ dalam penelitian ini diterima. Variabel empati $\left(\mathrm{X}_{4}\right)$ meliputi pelayanan dan perhatian yang baik pada semua pasien.

\section{Variabel Bukti fisik $\left(\mathbf{X}_{5}\right)$}

Berdasarkan uji $t$ diperoleh $t$ hitung $(2,846) \geq \mathrm{t}$ tabel $(1,99)$ dengan signifikansi o,oo6 menunjukkan bahwa Empati $\left(\mathrm{X}_{5}\right)$ mempunyai pengaruh yang signifikan terhadap kepuasan pasien (Y). Sehingga hipotesis kelima $\left(\mathrm{H}_{5}\right)$ dalam penelitian ini diterima. Variabel bukti fisik $\left(\mathrm{X}_{5}\right)$ meliputi kondisi fisik lingkungan poliklinik Mata Rumah Sakit Bhayangkara Semarang.

\section{KESIMPULAN}

1. Berdasarkan hasil penelitian dengan uji $\mathrm{F}$, menunjukkan adanya pengaruh secara bersama-sama antara variabel Keandalan $\left(\mathrm{X}_{1}\right)$, Keresponsifan $\left(\mathrm{X}_{2}\right)$, Keyakinan $\left(\mathrm{X}_{3}\right)$, Empati $\left(\mathrm{X}_{4}\right)$, Bukti fisik $\left(\mathrm{X}_{5}\right)$ terhadap Kepuasan Pasien rawat jalan di Poliklinik RS Bhayangkara Semarang. Hal ini ditunjukkan oleh F tabel $(40,831)$ lebih besar dari pada $F$ tabel $(2,486)$; 
2. Hasil analisis ini juga menunjukkan bahwa besarnya kontribusi variable-variabel Keandalan $\left(\mathrm{X}_{1}\right), \quad$ Keresponsifan $\left(\mathrm{X}_{2}\right)$, Keyakinan $\left(\mathrm{X}_{3}\right)$, Empati $\left(\mathrm{X}_{4}\right)$, Bukti fisik $\left(\mathrm{X}_{5}\right)$ yang ditunjukkan oleh nilai $R$ Square yaitu sebesar 0,734. Hal ini berarti bahwa kemampuan variabel-variabel Kualitas Pelayanan secara bersama-sama memberikan kontribusi terhadap Kepuasan Pasien sebesar 73,4 \%, sedangkan sisanya sebesar 26,6\% dipengaruhi oleh variabel lain;

3. Variabel Kualitas Pelayanan yang terdiri dari variabel Keandalan $\left(\mathrm{X}_{1}\right)$ memiliki pengaruh yang signifikan terhadap Kepuasan Pasien $(\mathrm{Y})$, Keresponsifan $\left(\mathrm{X}_{2}\right)$ memiliki pengaruh yang signifikan terhadap Kepuasan Pasien $(\mathrm{Y})$, Keyakinan $\left(\mathrm{X}_{3}\right)$ memiliki pengaruh yang signifikan terhadap Kepuasan Pasien (Y), Empati $\left(\mathrm{X}_{4}\right)$ memiliki pengaruh yang signifikan terhadap Kepuasan Pasien (Y), Bukti fisik $\left(\mathrm{X}_{5}\right)$ memiliki pengaruh yang signifikan terhadap Kepuasan Pasien (Y);

4. Berdasarkan uji t diperoleh $t$ hitung lebih besar dari $\mathrm{t}$ tabel, variabel Empati $\left(\mathrm{X}_{4}\right)$ merupakan variabel yang mempunyai pengaruh paling dominan terhadap Kepuasan Pasien pada Pasien rawat jalan Poliklinik Mata Rumah Sakit Bhayangkara Semarang.

\section{SARAN}

1. Dari hasil penelitian menunjukkan bahwa variabel Empati $\left(\mathrm{X}_{4}\right)$ merupakan variabel yang mempunyai pengaruh paling dominan terhadap Kepuasan Pasien pada Pasien rawat jalan Poliklinik Mata Rumah Sakit Bhayangkara Semarang apabila dibandingkan dengan keempat variabel bebas lainnya, sehingga disarankan untuk lebih meningkatkan hal-hal yang terkait dengan keempat variabel bebas lainnya. Khususnya variabel keandalan $\left(\mathrm{X}_{1}\right)$, yang terkait dengan kecepatan, ketepatan terhadap prosedur penerimaan pasien. Sebab variabel ini yang memiliki koefisien regresi terendah yaitu 0,118 .

2. Tingginya pengaruh variabel Empati $\left(\mathrm{X}_{4}\right)$ sangat sesuai dengan Rumah Sakit yang melayani pasien. Pada saat sakit, memang pasien sangat membutuhkan empati (Kopalle \& Lehmann, 2006) baik dari pihak medis ataupun pihak non medis (Panjami et al., 2019). Hal ini harus terus dipertahankan, bahkan sedapat mungkin untuk ditingkatkan.

3. Poliklinik Mata Rumah Sakit Bhayangkara Semarang perlu melakukan penelitian secara berkala untuk dapat mengetahui penilaian Kualitas Pelayanan yang diharapkan oleh pasien, sehingga tercipta kepuasan pasien.

\section{DAFTAR PUSTAKA}

Berry, L. L., Parasuraman, A., \& Zeithaml, V. A. (1988). SERVQUAL: A multiple-item scale for measuring consumer perceptions of service quality. Journal of Retailing, 64(1), 12-40. https://doi.org/10.1016/So1482963(99)00084-3

Chatzoglou, P., Chatzoudes, D., Vraimaki, E., \& Leivaditou, E. (2014). Measuring Citizen Satisfaction Using the SERVQUAL Approach: The Case of the 'Hellenic Post.' Procedia Economics and Finance, 9(Ebeec 2013), https://doi.org/10.1016/s2212349-360. 5671(14)ooo36-7

Cronin, J. J., \& Taylor, S. A. (1992). Measuring Service Quality: A Reexamination and Extension. Journal of Marketing, 56(3), 55. https://doi.org/10.2307/1252296

Guterman, Y. (2015). CUSTOMER SATISFACTION EVALUATION AND RECOMMENDATIONS FOR A Case: Business- Hotel “ Karelia .” December, 186.

Ismail, A., \& Yunan, Y. S. M. (2015). Service Quality As a Predictor of Customer Satisfaction and Customer Loyalty. Logforum, 12(4), 269-283. https://doi.org/10.17270/J.LOG.2016.4.7

Kesehatan, K., \& Indonesia, R. (2011). Kementerian Kesehatan Republik Indonesia Tahun 2011.

Kopalle, P. K., \& Lehmann, D. R. (2006). Setting quality expectations when entering a market: What should the promise be? 
Marketing Science, 25(1), 8-24. https://doi.org/10.1287/mksc.1050.0122

Krugman, H. E. (1965). The Impact of Television Advertising: Learning Without Involvement. Public Opinion Quarterly, 29(3), 349. https://doi.org/10.1086/267335

Mattila, \& S, A. (2001). Emotional bonding and restaurant loyalty. Cornell Hotel and Restaurant Administration Quarterly. Cornell Hotel and Restaurant Administration Quarterly, 42(6), 73-79.

Panjami, P., Lakshmi, L., \& Anoop, K. K. (2019). Impact of service quality dimensions on customer satisfaction in retail banking. Journal of Advanced Research in Dynamical and Control Systems, 11(4 Special Issue), 1002-1008.

Parasuraman, A. A., Zeithaml, V. A., \& Berry, L. L. (1991). Refinement and reassessment of the SERVQUAL instrument. Journal of Retailing, 67(4), 420-450.

Parasuraman, A., Zeithaml, V. A., \& Berry, L. L. (1985). A Conceptual Model of Service Quality and Its Implications for Future Research. Journal of Marketing, 49(4), 41. https://doi.org/10.2307/1251430

Prakash, G. (2019). Understanding service quality: insights from the literature. Journal of Advances in Management Research, 16(1), 64-90. https://doi.org/10.1108/JAMR-01-20180008

Tsiros, M., Mittal, V., \& Ross, W. T. (2004). The Role of Attributions in Customer Satisfaction: A Reexamination. Journal of Consumer Research, 31(2), 476-483. https://doi.org/10.1086/422124

Yousapronpaiboon, K. (2014). SERVQUAL: Measuring Higher Education Service Quality in Thailand. Procedia - Social and Behavioral Sciences, 116, 1088-1095. https://doi.org/10.1016/j.sbspro.2014.01. 350

Zeithaml, V. A., Berry, L. L., \& Parasuraman, A. (1996). The behavioral consequences of service quality. Journal of Marketing, $60(2)$, https://doi.org/10.2307/1251929

Zumrah, A. R. (2014). Service Quality in Malaysian Public Sector: The Role of
Transfer of Training. Procedia - Social and Behavioral Sciences, 144, 111-117. https://doi.org/10.1016/j.sbspro.2014.07. 279 